deviation from the normal, which, taken over a 3 -inch range in the first-order spectrum, only amounts to $0 \cdot 2 \AA$ 电sirön unit.

The important part played in solar and stollar spectroscopy by the $H$ and $K$ lines of calcium renders it essential that the absolute wave-lengths of these lines should be known with the greatest possible accuracy. For this reason Mr. C. St. John, working at the Mount Wilson Solar Observatory, has recently made a series of wavelength determinations for these lines in the arc, spark, and eiectric furnace, and in No. 2, vol. xxxi., of the Astrophysical Journal he gives his results in terms of the secondary standards of Fabry and Buisson adopted at the Meudon meeting of the International Solar Union. The mean results are 3968.476 and 3933.667 for $H$ and $K$ respectively, and are estimated to be certain within o.oor Angström. Mr. St. John also discusses the behaviour of these lines under the various conditions employed, and, from his results, concludes that the wave-lengths are identical for the absorption and the fine emission lines, and are the same in arc, spark, and furnace. The mean ratio of the width of $\mathrm{K}$ to $\mathrm{H}$ is $\mathrm{I} \cdot 28$, and the mean ratio of the respective intensitics is 1.47 . The experiments described were preliminary to an exhaustive comparative study of the corresponding solar lines.

\section{PLANT DISTRIBLTION.}

TWO recent papers furnish a supplement to the 1 magnificent plytogeosraphical memoir on South Africa by Dr. R. Marloth. The one is an article, by Dr. L. Diels, on formations and flora-elements in the north-ivest of Cape Colony, published in Engler's Botanische Jahr. bucher (vol. xliv., part i.). This is a detailed and localised account of botanical observations made in the country lying between the mouth of the Olifant River, Clanwilliam, and Calvinia. Near Clanwilliam lie sandy stretches where Compositæ and Scrophulariacex provide the bulk of the conspicuous vegetation. As the land riscs, succulents, notably species of Euphorbia and Crassulaceæ, become predominant. At a height of 500 metres the vegetation begins to show elements natural to the true Cape fora, culminating in a "proteaceous-macchi" association on the Boklieveld ridge. A special object of the trip was the exploration of the Hantam-berg flora, which is classed by the author with the botanical formations associated with Namaqualand.

The second paper is a contribution by Dr. H. H. W. Pearson to the Royal Geographical Society, published in the Geographical Journal (May), giving a general sketch of a botanical expedition through the dry western districts of Cape Colony and the adjoining German territory to Luderitzbuch, and thence from Mossamedes in Angola to Ft. Rosadas on the Kunene River. The regions of vegetation through which Dr. Pearson travelled are very clearly set out in the accompanying map. The succulent Karroo vegetation was first traversed until this gave place to a conposite flora near Calvinia. Further north, floras known as the Namaqualand montane and Bushmanland were met with. The former is characterised by the presence of Aloe dichotoma, Vogelia africana, and other plants, while species of Aristida and Parlinsonia africana are typical of the latier type. The district lying immediately south of Mossamedes is the historic locality in which Welwitschia was discovered, and here the author found it more at home than in Damaraland, which suggests that it is a tropical species, and therefore more closely related to the genus Ginetum than to Ephedra.

Attention is frequently directed to weeds produced in new countries by exotic plants. There is, however, more interest attaching to the spread of indigenous plants caused by a disturbance of natural conditions, of which a striking instance in the case of Celmisia spectabilis is described by: Dr. L. Cockayne in the Canterbury $\Lambda$ griculturists and llanters Association's Journal (April). This plant is a romposite and endemic, growing naturally with other species of the genus at elevations above 3000 feet. It has a woody, creeping stem furnished with numerous cord-like ronts. The end of the stem bears a rosette of thick tomentose leaves with long sheathing bases; the rosettes are crowded together, forming a circular mat or cushion. Within the shelter of the leaves lies the bud, which throws out daisy-like flowers above the leaves, and subsequently deveiops downy fruits. As a result of burning and overgtazing, the tussock formations at a lower level, which consist of uscful grasses, are being replaced by the Celmisia. The remedy suggested is to reinstate natural conditions, when the grasses should win back the lost ground.

Captain A. A. Dorrien-Smith contributes to a recent number of the Kew Bulletin (No. 4) an account of his botanical excursions in Chatham Island with the primary object of collecting specimens of Olcaria semidentata, Acrphylla Dieffenbachii, and other local plants for introduction into the Scilly Isles. In the south and boggiest part of the island Olcaria semidentata covers acres of ground, and here the author discovered a pure white form of this normally purple daisy-like flower, and his companion found a pink variety. The article provides an interesting sketch of the vegetation, and is illustrated with several photographs, two of which represent bushes of the normal type and white variety of the Olearia respectively.

\section{THE MAINTENANCE AND ADMINISTRATION} OF RO. $R D S$

$A$ UTHORITIES having control of highways have now to consider the problem of road construction and maintenance from a new point of view in consequence of the conditions of modern traffic. The problem is an acute one everywhere, and various solutions of it have been put forward by highway engineers. Evidence of experts as to the causes of the increased wear and tear of roads and their opinions as to remedies will be found in the report of the important conference on roads, held last year at the Institution of Civil Engineers, and also in various publications of the Roads Improvement Association and the Roval Automobile Club. The subjoined extracts from these publications, and summaries of papers, provide the essence of a large amount of evidence given by road engineers befo:e several conferences and associations upon important questions relating to roads.

A very large number of our roads, except those of recent construction, may be said to have grown, or developed, rather than to have been made. Many of them were originally mere tracks, and have arrived at their present state through the accretion of coats of ground-up stone, often of poor character, possibly faced with a thin crust of granite or some inferior material. The fact that many roads have been built up by the use of metalling, without foundations, other than the subsoil upon which the metalling is placed, accounts for the difficulties, troubles, and expensive maintenance now experienced in connection with most existing rural main roads, for where the foundation of a road is weak, the surface is always difficult and costly to maintain.

The greatest practicable improvement in the construction of macadamised roads is to be found in the use of the very hardest and toughest coating materials well consolidated by rolling, with the addition of iust sufficient fine chippings during the consolidating process to fill completely the spaces between the stones. The common method (condemned by every road engineer) of binding together the asgregate of an ordinary macadam road by the use of road scrapings is productive of the greater part of the mud and dust found so objectionable. One of the resolutions referring to macadamised roads adopted by the International Road Congress held at Paris in 1908 was :- "To use as far as possible only hard and homogeneous road materials, regularly broken; to make choice of a binder suitable to the structure of the road material used, reducing, moreover, the binder to a minimum."

As to the wearing characters of various rocks used as road metals, some definite information is available. The Town Council of Hornsey possesses a machine by which the effect of wear and tear on road stones can be tested. The stones to be tested are all broken to a 2 -inch gauge and placed in cast-iron cylinders, which are made to revolve 8000 times at a speed of twenty revolutions a minute. They are tested both wet and dry, and as the result of the shaking they receive a certain amount of chips and dust is produced. The percentage loss of weight experienced by the stones is then determined. As the treatment is the NO. 2 I $2 \%$, VOL. 84] 